\title{
Research on Physical Education and Modern Human Evolution
}

\author{
Jiang Xia \\ Jiangxi College Of Foreign Studies
}

\begin{abstract}
Physical education plays a big role in human evolution. By studying the status and role of physical education on human evolution, we can cognize physical education from a new perspective of human origin, existence and development and enrich the knowledge hierarchy and theoretical framework of physical anthropology. It is also good for people to realize the severe deficiencies of current physical education to force us to actively seek the countermeasures to promote the healthy and orderly development of human beings. This paper analyzes the factors affecting human evolution, including natural selection, environment variation, labor, science and technology progress, sports and physical exercise . In the end, it analyzes the acceleration to human evolution of physical education.
\end{abstract}

Keywords-Physical education; Human evolution; Aesthetic psychology

\section{INTRODUCTION}

Sports hols an important position in the history of human civilization and its development is closely related to the progress of human society .It's even can be said the development of sports is an important sign of human society progress. As a special cultural phenomenon of human society, sports not only embodies the relationships between human and nature, human and human, human and its inner world as well as the concept change resulted but also reflects the relationship change of social life including human social political, military, economy and culture. As we see, physical education plays a big role in promoting human evolution. Studying the status and role of physical education in modern human evolution not only has an important theoretical significance but also has distinctive times value.

This paper can enrich the knowledge hierarchy and theoretical framework of physical anthropology .Physical anthropology is a new discipline emerged in the 1980's at home and abroad .It comprehensively studies the sports issues from physique and cultural aspects. As the best combining point of physique anthropology and culture anthropology, it is a bridge discipline and making its unique contributions in terms of promoting the fusion of anthropology. From sports field, physical anthropology studies human comprehensive sustainable development, reveals and analyzes human beings physique and factors related to physical education in culture. It from the long process of human development studies the general rules of physical education and its specific form in theory, reveals the internal structure in physical education, and find the common rules in physical education process and similar social phenomenon.

\section{PHYSICAL EDUCATION}

"Physical education" was first used in 1930', and then continued to be used, but unable to be used widely. In the 1950's, though our sports theory cycle had discussed "sports noun concept", the problem of mixing of "sports" and "physical education" had not been solved. Until the end of 1980's, "physical education" was officially used in legal documents issued by the national education commission. Scholars see "physical education" concept from different point of view, so different explanations are put forward .They are mainly the following:

(1) Physical education is an education that teaches sports knowledge, skills and technique.

(2) Physical education is to accept political education and military education.

(3)Physical education is an education referring to physical education with the main task of developing body and enhancing physique.

(4) Physical education is an education process with a purpose and plan, by physical activity, enhance physical fitness, teaching the knowledge ,skills and technique, and cultivate moral and will quality .It's a component part of education and an important aspect to cultivate all-round development of people.

Physical education refers to a conscious and purposeful physical education process which is according to the needs of production and life to enhance physical fitness and promote people's all-round development of body and mind, follows the rules of body growth and development, takes physical exercises as basic means.

The aesthetic psychology research of physical education

The aesthetic psychology research of physical education is mainly to construct students' aesthetic psychology in physical education. Aesthetic psychological structure is a compound of various psychological contents and forms. Various psychology contents and psychology forms as well as the psychology contents and psychology forms are not isolated but connected. Each psychology content or psychology forms development is both on the basis of other psychology contents and psychology forms and directly or indirectly drive the development of other psychology contents or psychology forms. Aesthetic psychology research involves many aspects, mainly include aesthetic perception, aesthetic imagination, aesthetic will, aesthetic understanding, aesthetic creation, aesthetic emotion, aesthetic taste, aesthetic ideal, aesthetic concept, aesthetic synaesthesia, aesthetic 


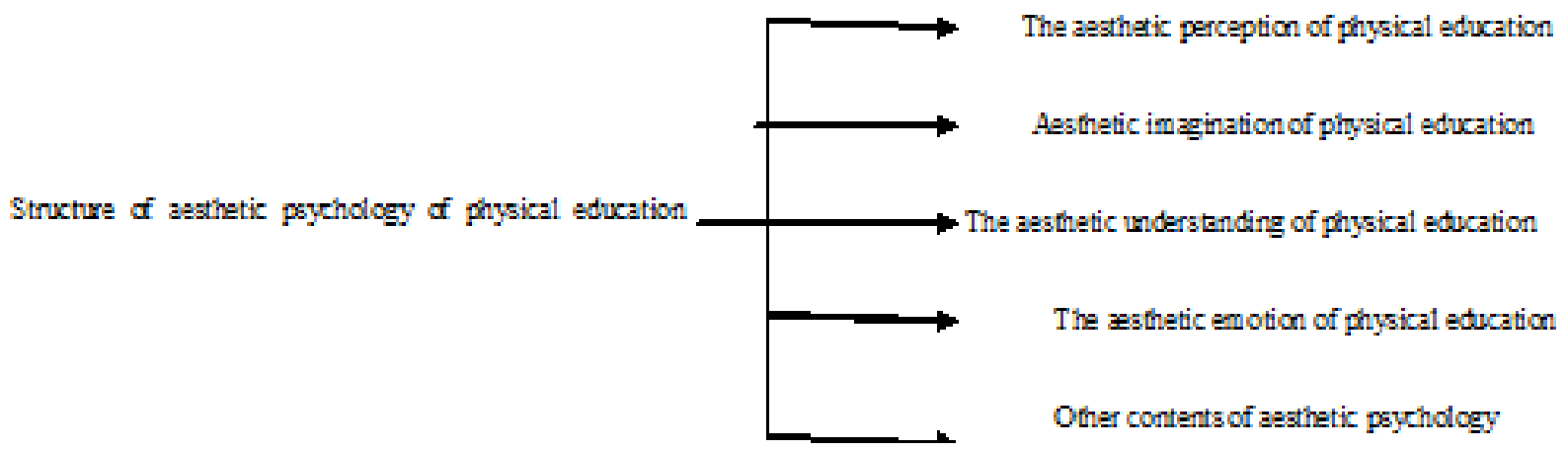

Figure 1. The psychology structure of physical education

\section{THE RELATIONSHIP BETWEEN PHYSICAL EDUCATION AND HUMAN EVOLUTION}

In the course of human evolution, natural selection plays an important role. Natural selection has the role of genetic variation and evolution direction, thus promotes species differentiation. It's the core content of Darwin's theory of evolution. Darwin's theory of evolution thinks that the biological evolution is determined by gene mutation, natural selection and reproductive isolation. The mutation which is suitable for the living environment will be preserved in natural selection, otherwise will be eliminated. This is "Survival of the fittest." Natural selection plays the role of identifying and orienting the gene mutation during mutation and selection. This role is objective material force and changes with the environment change.

Some scholars analyzed the positive role of sports to human evolution. For example: Anthropologists from Harvard University and University of Utah think running may be a key factor in the process of human evolution after they analyzed comprehensively the physiological characteristics of human bone fossil millions of years ago. On the relationship of brain and sports ability from biological evolution and human society developing process reviews the modern disease caused by the highly-developed brain and increasingly degraded body movement ability by analyzing the relationship between sports ability of human beings and brain. On the role of original gymnastics in human evolution thinks original gymnastics plays an irreplaceable role in human evolution by elaborating the process of human evolution and the factors promoting human evolution. Some scholars believe that sports must be people-oriented, reflect the care and respects to human being .That's the inevitable end to sports. Sports will provide happiness in means of fostering human healthy body, trying to maintain the survival vitality of human being as a species. Recently, some scholars pay high attention to the health problems of the intellectuals and they think that the long-term mental labor and physical labor doesn't match and it disturbs and damages the balance of human body life system and harms the health of body and mind. Physical exercise is the most effective means of nature to reconcile the conflict and maintain the ecological measures of modern life balance system.

\section{CONCLUSION}

The study and recognition to body in physical education can not only directly promote the further development of physical education but also has a profound influence on the development of human beings. Body is a kind of perspective and a window to observe the world. The cognition and study to body in fact is not only a kind of cognition and study to human but also to the world. At the entrance of the ancient Greek temple at Delphi engraved an eternal saying --Know yourself. To truly know you, it's an inevitable choice to review yourself. To know this world, we must first start from the body. As the most direct manifestation of culture, physical education is closely connected to body. Physical education is an education form the direst education form acting on body. As a result, the study and recognition to body in physical education can not only directly promote the further development of physical education but also has a profound influence on the development of human beings.

\section{REFERENCES}

[1] Tong L. The Positive Influence of Sports for Mental Health[J]. Journal of Beijing Teachers College of Physical Edueation, 1999.

[2] Tong, Lichun. "The Positive Influence of Sports for Mental Health." Journal of Beijing Teachers College of Physical Edueation (1999).

[3] Yang G. Comparison Between the Originality of Sports Education Majors Home and Abroad[J]. Journal of Beijing Teachers College of Physical Edueation, 2000.

[4] Wang H. Superficial Analysis on a Few Kinds of Sports Teaching Model Present Teaching Practice in Our Country[J]. Journal of Beijing Teachers College of Physical Edueation, 1999.

[5] Hong-Qun L I. The Acsthethic Education in Sports Activities[J] Journal of Physical Education Institute of Shanxi Teachers University, 2001. 
[6] Hong-Qun, L. I. (2001). The acsthethic education in sports activities. Journal of Physical Education Institute of Shanxi Teachers University.

[7] Yan H, Liu Y, You Y. Study on Individual Tactics Awareness and Trainning Self-confidence in Modern Basketball Contest[J]. Journal of Zhoukou Teachers College, 1999.

[8] Acco. Sport Educatie: leren van en met elkaar[M] Acco, 2014.

[9] Milanović D, Jukić I. Evaluation in top level sport[J]. Zbornik radova 13. ljetne škole kineziologa Republike Hrvatske «; Vrednovanje u području edukacije, sporta i sportske rekreacije»; / Findak, Vladimir, 2004
[10] $\mathrm{Li} \mathrm{H}$. The on |spot Strategy of the Coach During Basketball Contest: Its Design and Application[J]. Journal of Beijing Teachers College of Physical Edueation, 1999.

[11] Zhao Li. Probe into the theory and practice of 'enjoyment physical education'[J]. Journal of Beijing Teachers College of Physical Edueation, 1999.

[12] Xiao-Ming L I, Dai H Y, Jin X F, et al. The Analysis on the Necessity of Inheriting Ethnic Traditional Sports Education[J]. Zhejiang Sport Science, 2011. 